\title{
STUDY OF THE TECHNOLOGY OF STRENGTHENING BRICK WALLS BY EXTERNAL REINFORCEMENT
}

\section{Molodid O. S.}

\section{INTRODUCTION}

From the analysis of technical inspection reports developed by the State Enterprise "V.S. Balitsky Research Institute of Building Production", it has been established that $85 \%$ of brick buildings over 30 years of age have cracks on their walls. Such cracks appear on one side of the wall or can be through-thickness, diagonal, horizontal or vertical, through brick joints and with brick breaks. As a rule, their width ranges from $0.1 \mathrm{~mm}$ to $70 \mathrm{~mm}$. (fig. 1).

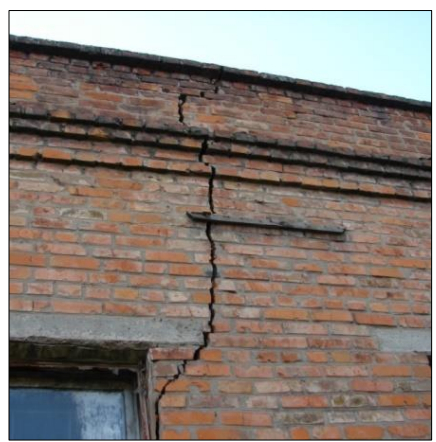

Fig. 1. A diagonal crack on a brick wall with a width ranging from 25 to $45 \mathrm{~mm}$

The causes for brickwork fracture are ${ }^{1}$ :

- increased load on these constructions due to the replacement or strengthening of upper constructions (heightening, adjacent accommodation) or replacement of technological equipment (file benches, lifts, escalators, cranes etc.) by items whose mass exceeds the mass of the ones used before the reconstruction;

- loss of bearing strength caused by operation: dynamic load, corrosive operational environment or atmosphere, improper operation (corrosive

\footnotetext{
1 Савйовський В. В. Реконструкція будівель і споруд / В.В.Савйовський. - К.: Видавництво Ліра-К, 2018. - 320 с.
} 
substances spill, leaks in water supply systems and sewage, weather), random damages, accidents.

In accordance with the National Standards of Ukraine DSTU-N B V.1.2-18:2016 ${ }^{2}$ and DSTU B V. 3.1-2:2016, vertical and diagonal cracks crossing not more than two courses of masonry and other cracks with the width under $0.5 \mathrm{~mm}$ need either injection or caulking. The walls with vertical and diagonal cracks whose width ranges from 0.5 to $50 \mathrm{~mm}$ require filling and strengthening or re-laying of brickwork.

Normally, strengthening of masonry constructions requires much less costs than replacement thereof; however, it calls for a responsible and highly qualified approach to the carrying out of a set of complicated construction works.

The main objective of strengthening of masonry structures is to increase its bearing strength and reinforcing elements after their performance has been reduced due to the influence of various factors or in case additional strength needs to be added to the elements.

The decision on the technical feasibility and economic efficiency of strengthening masonry construction in each individual case is taken with due consideration of their state and performance characteristics.

Current regulations ${ }^{1}$ and technical literature ${ }^{4,5}$, offer the following ways of strengthening or restoring the bearing strength of brick walls:

- full or partial replacement of the existing brickwork;

- injection of cracks;

- introduction of various strengthening elements;

- external reinforcement.

The most efficient ways of strengthening masonry structures is the installation of ferrocement, reinforced brick, reinforced concrete or steel casings ${ }^{3}$.

Currently, external reinforcement, i.e. steel plates welded into a frame and fixed to a wall with anchors (fig. 2) is widely used in Ukraine for strengthening brick walls. However, the technology of such strengthening is complicated and labor-intensive, as it is connected with the need to perform

2 ДСТУ-Н Б В.1.2-18:2016 Настанова щодо обстеження будівель і споруд для визначення та оцінки їх технічного стану. - Київ: ДП «УкрНДНЦ», 2017. - 47 с.

${ }^{3}$ ДСТУ Б В.3.1-2:2016 Ремонт і підсилення несучих і огороджувальних будівельних конструкцій та основ будівель і споруд. - Київ: ДП «УкрНДНЦ», 2017. - 72 с.

4 Савйовський В. В. Реконструкція будівель і споруд / В. В. Савйовський. - К.: Видавництво Ліра-К, 2018. - 320 с.

5 СТО 221 НОСТРОЙ 2.9.142-2015 Восстановление и повышение несущей способности кирпичных стен Проектирование и строительство. Правила, контроль выполнения и требования к результатам работ. - М.: «Издательство «БСТ», 2013. - 114 с. 
welding and fix the plates with anchors, especially when these works are performed at heights.

It should be mentioned that when strengthening long wall constructions, difficulties may arise with stringing horizontal steel plates to engage them in operation. Therefore, sometimes the plates meant for strengthening sag and overload the construction of the walls.

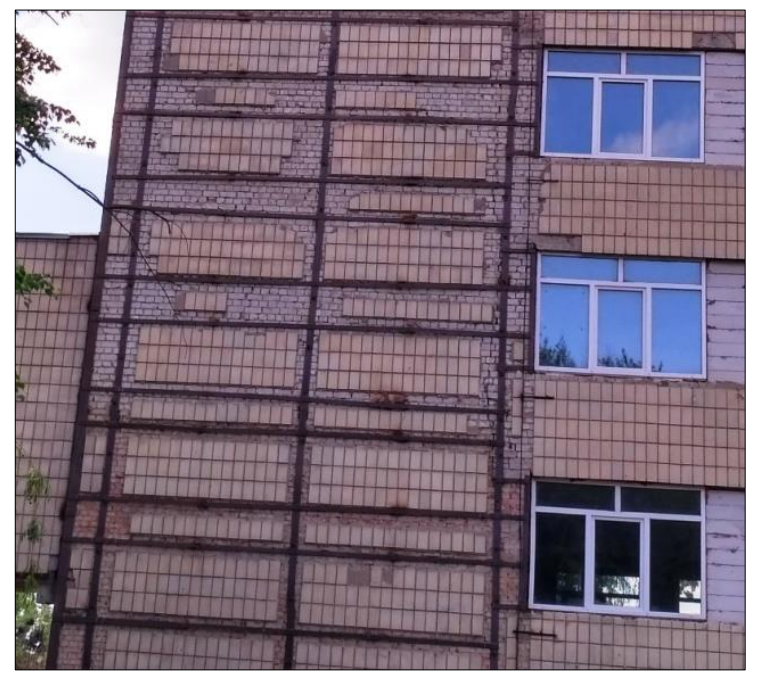

Fig. 2. Strengthening of brick walls with external reinforcement, i.e. steel plates

It should be mentioned that works of foreign scholars, 7 provide extensive coverage to design and technology solutions for strengthening brick walls with external reinforcement using composite fibers, plates (lamellae) or nets fixed to the wall surface.

The technology of strengthening constructions with composite fibers lies in gluing of high-strength plates with a special epoxy glue or microcementbased glue onto the construction surface. The strengthening is performed on the prepared surface with pre-coated base. Both strengthening of bending constructions in the tension areas and pre-heel areas in the action areas of lateral forces and compression elements and beam columns is possible.

${ }^{6}$ Angelo Garofano. Structural behaviour of masonry walls strengthened with mortar layers reinforced with FRP grids. Master's Thesis. - Czech Republic, 2011. - 124 p.

${ }^{7}$ Saman Babaeidarabad. Masonry walls strengthened with fabric-reinforced cementitious matrix composite subjected to in-plane and out-of-plane load. Dissertation. - Coral Gables, Florida, 2013. - 147 p. 
Similar research has been conducted by A.N. Kostenko ${ }^{8}$, who carried out a series of compression tests of brick piers reinforced by carbon fabric bandages. In the course of these tests, it was established that the bearing strength of brick piers can be increased nearly twofold as compared to the reference. Samples were tested by compression and bending. The test results demonstrated that, when carbon fiber is used, the laying strength under compression increases approximately 2-2.4 times (depending on the reinforcement pattern of the sample). The reinforcement patterns are shown in figure 3.

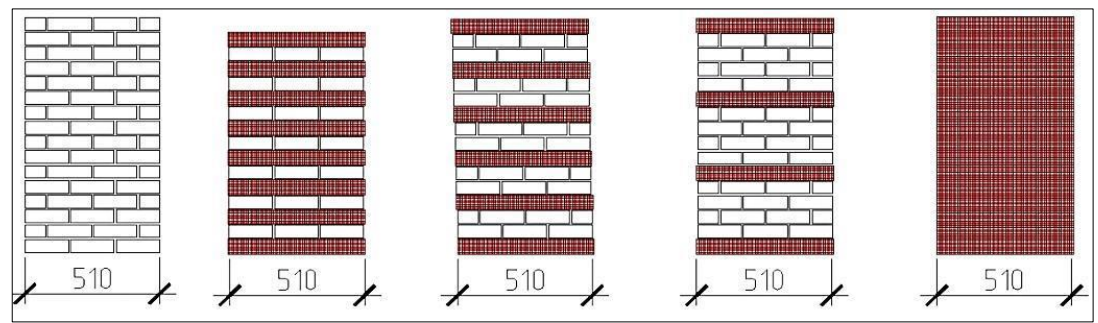

\section{Fig. 3. Patterns of brick piers reinforcement with composite grids during sample compression tests}

The top efficiency was shown by the samples completely covered with grids. As per the tests, the relative strength increased 2.6 times. However, a number of unsolved issues is connected with this configuration of strengthening. Such strengthening of the construction excludes brickwork vapor permeability. Besides, the wrecking of the brickwork becomes random, as the ability to control crack formation is lost.

It should be noted that information on such ways of strengthening brick walls is virtually unavailable in Ukrainian scientific, technical and regulatory literature.

In view of the above, the author made a decision to research the technology of strengthening brick walls with external reinforcement glued to the reinforced constructions, where domestic materials were used.

\footnotetext{
${ }^{8}$ Костенко А. Н. Прочность и деформативность центрально и внецентренно-сжатых кирпичных и железобетонных колонн, усиленных угле- и стекловолокном. Автореферат диссертации на соискание ученой степени кандидата технических наук, Спец. 05.23.01. M., 2010. 29 c.
} 


\section{Experimental tests, Stage I.}

At this stage, experimental tests were conducted to establish the dependence of the strength of adhesion of the reinforcement element glued to the brick to on the influence of such technological factor as base preparation.

The tests was conducted in two series, each of which consisted of five hollow type M100 clay bricks.

The main task of these experimental tests was to define the strength of adhesion with the base of the metal plates glued (the attachment area was $25 \mathrm{~cm}^{2}$ ) to a prepared lateral surfaces (stretchers) of the bricks. The surfaces of separate bricks were prepared by soaking with Consolid-1 deeply penetrating epoxy-based primer manufactured by COMPOSIT LLC.

In the first series of the tests, one stretcher of the test brick was divided into three equal parts. No manipulations were made with the first part. The second part was evenly covered with a single coat of Consolid-1 primer with a brush (with the rate of application $370 \mathrm{~g} / \mathrm{m}^{2}$ ). The third part was first covered with one coat of Consolid-1 primer $\left(370 \mathrm{~g} / \mathrm{m}^{2}\right)$, and 24 hours later with another coat of the same primer at the rate of application of $200 \mathrm{~g} / \mathrm{m}^{2}$.

In the second series of the tests, one stretcher of each tested brick was divided into two parts. The first part was covered with ten coats of Consolid1 primer with the rate of application for each coat $300 \mathrm{~g} / \mathrm{m}^{2}$. Each subsequent coat of primer was applied after the previous had soaked into the brick. The same manipulations were made with the second part of the bricks, but the number of coats was increased up to 30 .

Twenty-four hours after the last coat of primer had been applied, a metal plate was glued to on each separate part of the prepared and unprepared brick surface (fig. 4). The plates were glued with EDMOK epoxy-based glue manufactured by COMPOSIT LLC.

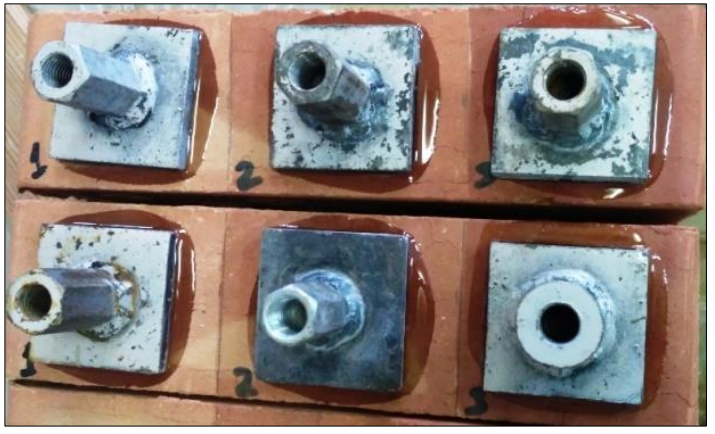

Fig. 4. Plates glued to bricks stretchers in the first series of tests 
In two days after the plates were glued, a coat of glue was cut along the perimeter of the plates down to the brick, after which the plates were torn away with the help of an adhesiometer.

The results demonstrated that all metal plates were torn with fragments of the bricks, and the size of these fragments and the force with which the plates tore off depended on the technology of the base preparation (fig. 5) (table 1).
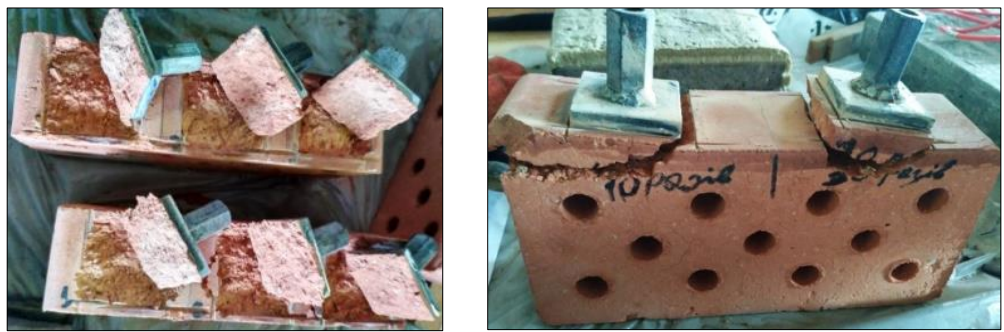

Fig. 5. Torn-off plates with fragments of bricks

Table 1

Test results for tearing off plates glued to bricks

\begin{tabular}{|c|c|c|c|c|c|c|}
\hline \multirow[t]{2}{*}{ No. } & \multirow[t]{2}{*}{$\begin{array}{c}\text { Test } \\
\text { series }\end{array}$} & \multirow[t]{2}{*}{$\begin{array}{c}\text { Test } \\
\text { number }\end{array}$} & \multirow[t]{2}{*}{$\begin{array}{l}\text { Application rate } \\
\text { of Consolid-1 } \\
\text { primer for base } \\
\text { preparation, } \mathrm{g} / \mathrm{m}^{2}\end{array}$} & \multicolumn{2}{|c|}{$\begin{array}{c}\text { Average force of } \\
\text { tearing plates off } \\
\text { bricks }\end{array}$} & \multirow{2}{*}{$\begin{array}{c}\text { Thickness of } \\
\text { the torn-off } \\
\text { brick } \\
\text { fragment, } \mathrm{mm}\end{array}$} \\
\hline & & & & MPa & $\%$ & \\
\hline 1 & \multirow{3}{*}{1} & 1 & 0 & 1.09 & 100 & $1-3$ \\
\hline 2 & & 2 & 370 & 1.21 & 111.0 & $2-4$ \\
\hline 3 & & 3 & 570 & 1.32 & 121.1 & $2-5$ \\
\hline 4 & \multirow{2}{*}{2} & 4 & 3000 & 2.26 & 207.3 & $5-8$ \\
\hline 5 & & 5 & 9000 & 2.81 & 257.7 & $7-10$ \\
\hline
\end{tabular}

The test results (table 1) were used to build a histogram (fig. 6) of the average force of tearing plates off the bricks at different application rates of the primer used for base preparation.

The analysis of the experimental test results enables us to state that preparing bricks surface before reinforcement elements are glued to it influences the strength of adhesion with the base. When it permeates the brick structure, Consolid-1 primer strengthens it, whereby, when a metal plate is torn off, a fragment of the brick is torn of with it, and the tearing dept of the fragments grows with the increase of primer application rate when applying it to the brick surface. 


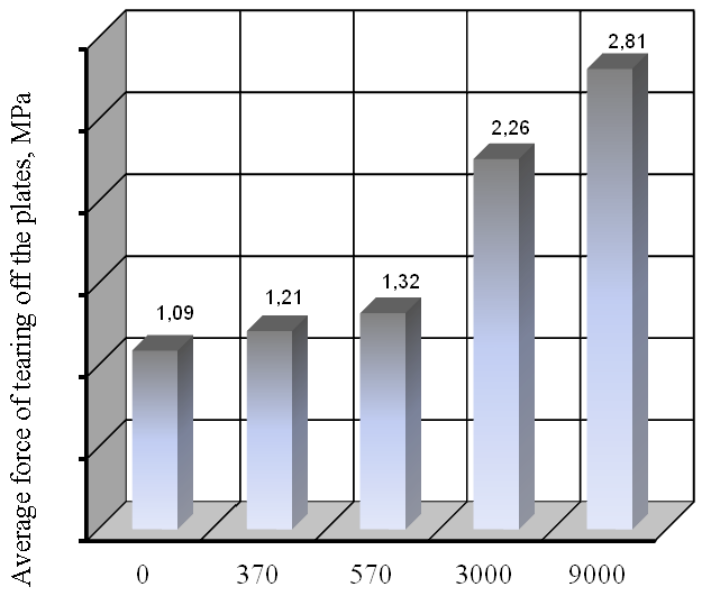

Primer application rate for base preparation, $\mathrm{g} / \mathrm{m}^{2}$

\section{Fig. 6. Histogram of the average force of tearing plates off the bricks at different primer application rates for base preparation}

For example, the average force of tearing off a plate from a brick with an unprepared surface was $1.09 \mathrm{MPa}$, and the average force of tearing off of plates from bricks whose surface was covered with $570 \mathrm{~g} / \mathrm{m}^{2}$ of primer is $1.32 \mathrm{MPa}$, which is $21.1 \%$ more.

It should be mentioned that application of $9,000 \mathrm{~g} / \mathrm{m}^{2}$ of primer on the brick surface raises the average tearing force of plates to $2.81 \mathrm{MPa}$, which is $157.7 \%$ more as compared to the force of tearing off plates from untreated bricks.

\section{Experimental tests, Stage II}

The main task of this stage of experimental tests was to find effective methods of strengthening of brick constructions with external reinforcement. The bricks were reinforced by gluing steel plates or carbon fiber strips to their lateral surfaces (stretchers). The surface of separate bricks was prepared by soaking with Consolid-1 deeply-penetrating primer manufactured by COMPOSIT LLC. Preliminary marked areas of adhesion of strengthening elements were evenly covered with tree coats of primer with a brush with a total rate of application of $1,100 \mathrm{~g} / \mathrm{m}^{2}$.

Twenty-four hours after the last coat of primer had been applied, strengthening elements were glued to the prepared and unprepared brick surfaces (fig. 7). The elements were glued with EDMOK epoxy-based glue manufactured by COMPOSIT LLC. 
The following methods of brick strengthening are foreseen (fig. 7):

1. non-strengthened bricks;

2. steel plates (30 $\mathrm{mm}$ in width, $2 \mathrm{~mm}$ in thickness) fixed with glue and mechanically secured with anchors;

3. carbon fiber strips ( $30 \mathrm{~mm}$ in width, with density of $300 \mathrm{~g} / \mathrm{m}^{2}$ ) fixed with glue;

4. steel plates (30 $\mathrm{mm}$ in width, $2 \mathrm{~mm}$ in thickness) fixed with glue;

5. brick surfaces coated with primer, with steel plates $(30 \mathrm{~mm}$ in width, $2 \mathrm{~mm}$ in thickness) glued to them 24 hours later. The plates were additionally pressed to the bricks;

6. brick surfaces coated with primer, with carbon fiber strips $(30 \mathrm{~mm}$ in width, with density of $300 \mathrm{~g} / \mathrm{m}^{2}$ ) glued to them 24 hours later;

7. brick surfaces coated with primer, with two carbon fiber strips (30 mm in width, with density of $300 \mathrm{~g} / \mathrm{m}^{2}$ ) glued to each of the surfaces 24 hours later.

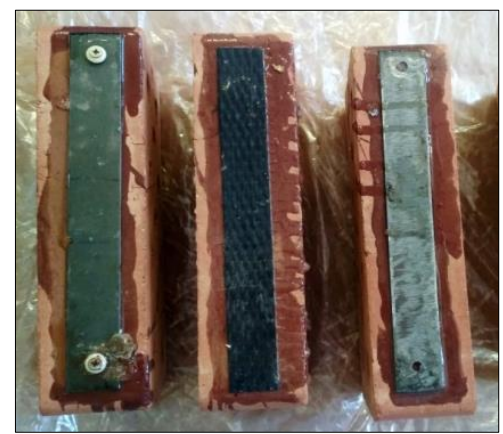

№ 2 № 3 № 4

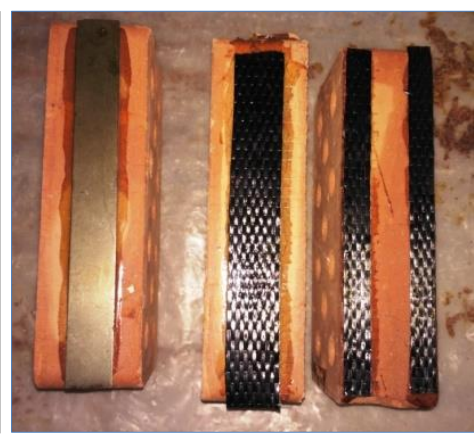

№ 6

№ 7

Fig. 7. Bricks strengthened by various methods

Two days after gluing the strengthening elements, the bricks were tested for bending strength. The tests were conducted on hydraulic press PSU-10.

For a static diagram, the tests were conducted as for a free-ended beam with $220 \mathrm{~mm}$ width. The bricks were loaded with concentrated force in the middle of the brick (fig. 8).

The load was applied to the bricks in stages with gradual load increase of $20 \mathrm{~kg}$ at each stage with 1-minute delay. The tests were conducted until the bricks lost their strength. The results of the experimental tests are given in table 2. The fracture patterns of strengthened or non-strengthened bricks are shown on fig. 9 . 

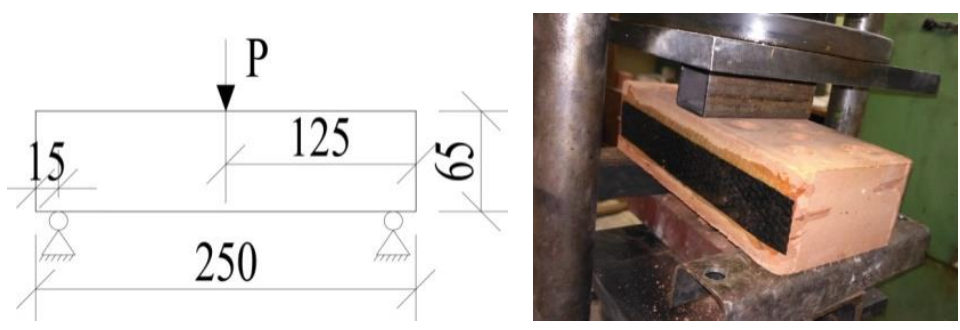

Fig. 8. Diagram and photo of applying load to tested bricks

Table 2

Results of the tests for tearing the plates off the bricks

\begin{tabular}{|c|c|c|c|}
\hline $\begin{array}{c}\text { No. of test } \\
\text { series }\end{array}$ & \multicolumn{2}{|c|}{ Average breaking force, } & \multirow{2}{*}{ Brick fracture pattern } \\
\cline { 2 - 3 } & $\mathbf{k g}$ & 100 & Broke in halves \\
\hline 1 & 70 & 685.7 & $\begin{array}{c}\text { Broken fragments were held in } \\
\text { place by the plates }\end{array}$ \\
\hline 2 & 480 & 728.5 & Same \\
\hline 3 & 510 & 607.1 & $-/ /-$ \\
\hline 4 & 425 & 978.5 & $-/ /-$ \\
\hline 5 & 685 & 842.8 & $-/ /-$ \\
\hline 6 & 590 & 407.1 & $-/ /-$ \\
\hline 7 & 285 & & \\
\hline
\end{tabular}

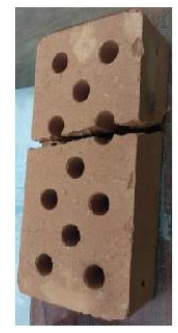

No. 1

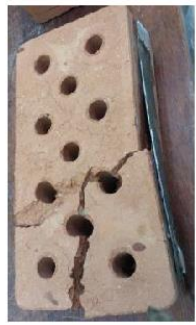

No. 2

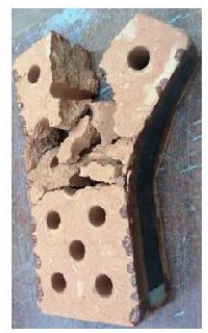

No. 3

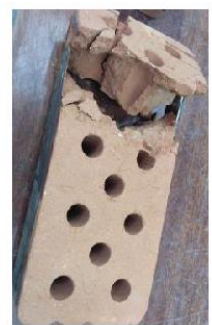

No. 4

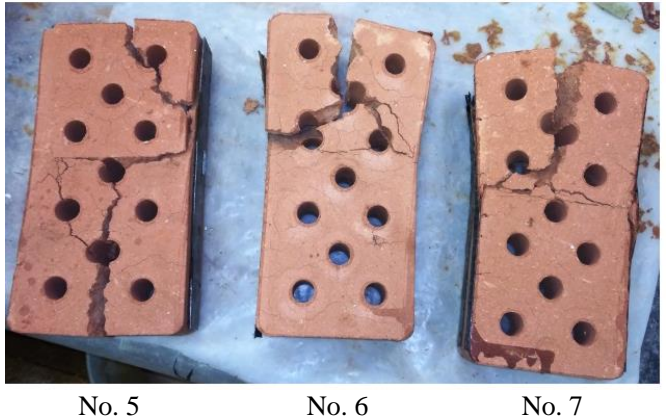

No. 5

No. 6

No. 7

Fig. 9. Brick fracture pattern upon undergoing strength tests 
Based on the experimental tests results (table 2) a histogram (fig. 10) of the average breaking force of the bricks strengthened with different methods was built.

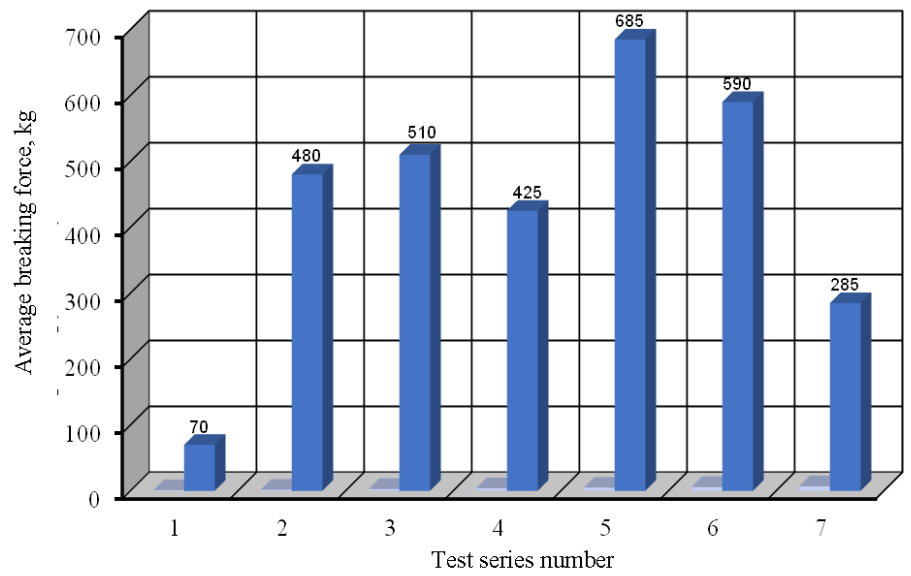

Fig. 10. Histogram of the average breaking force in different methods of brick strengthening

The analysis of experimental test results allows to claim that strengthened bricks can withstand significantly larger loads as compared to non-strengthened ones. It should be mentioned that the bending strength of a brick strengthened by two steel plate is $425 \mathrm{~kg}$, and the bending strength of a brick strengthened by the same method with additional fixing with anchors is $480 \mathrm{~kg}$. In addition, if bricks are strengthened with steel plates glued to the surface pre-coated with primer, its strength will increase up to $685 \mathrm{~kg}$, which is 9.7 times higher as compared with the strength of non-strengthened bricks.

\section{Experimental tests, Stage III}

At his stage, seminatural experimental tests of the technology of strengthening brick walls with external reinforcement were planned with the use of the results of the tests conducted at the previous stages.

For this purpose, three half-brick walls were prepared, made of M100 hollow ceramic bricks with M100 cement and sand grout. The height of the walls was $520 \mathrm{~mm}$, the length $-1,040 \mathrm{~mm}$.

The experimental tests plan provided for the following ways of walls strengthening:

- wall No.1 - non-strengthened (reference sample); 
- wall No. 2 - strengthened on both sides with steel plates fixed on EDMOK modified epoxy-based glue on the upper and lower parts of the wall. At the edges the plates are additionally fixed with anchors (fig. 11, a);

- wall No. 3 - strengthened on both sides with carbon unidirectional fibers fixed on EDMOK modified epoxy-based glue on the upper and lower parts of the wall (fig. 11, b)

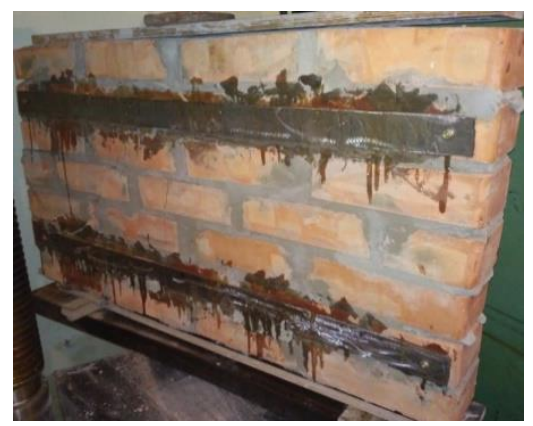

a

- wall No. 4 is wall No.1, which, after testing, was glued with EDMOK glue and strengthened with carbon unidirectional fibers fixed on EDMOK glue on the upper and lower parts. Before strengthening, the areas to which the fibers were glued on wall No. 4 were coated with Consolid 1 deeply penetrating epoxy-based primer (a total of 4 coats were applied).

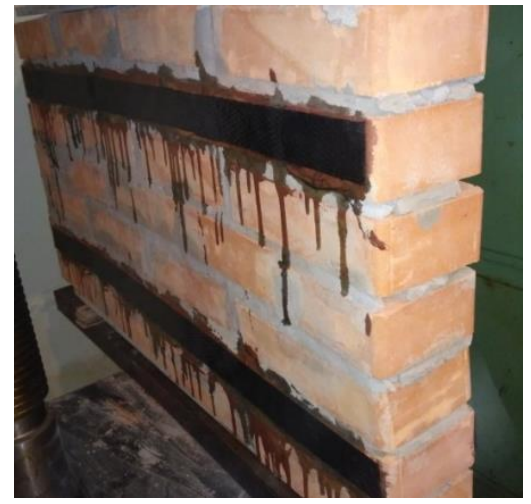

b

Fig. 11. Strengthened walls:

$\mathrm{a}$ - with steel plates; $\mathrm{b}$ - with carbon fibers 
Two days after the strengthening elements were glued to them, the walls were tested for bending strength with the help of PS-50 hydraulic press (fig. 12).

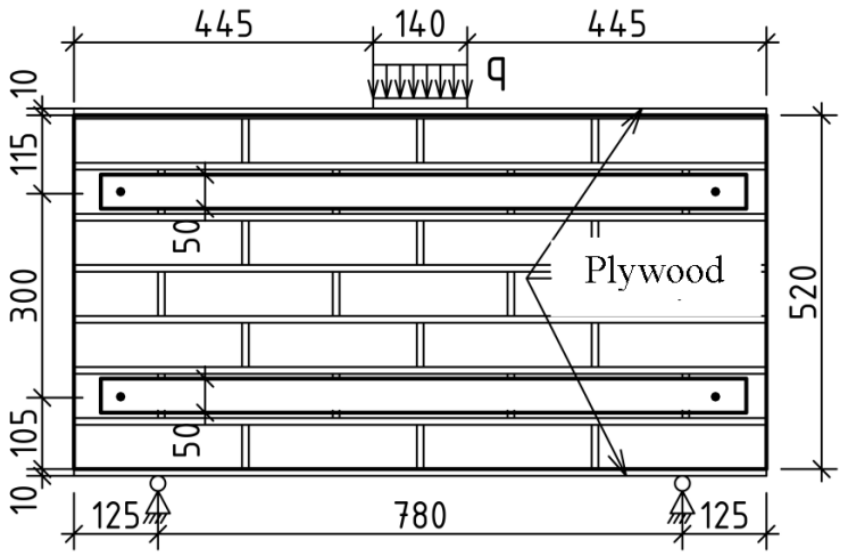

Fig. 12. Scheme of applying load to the walls

The experimental test results are displayed in table 3 and fig. 13.

Table 3

\section{Results of testing walls for bending strength}

\begin{tabular}{|c|c|c|l|}
\hline \multirow{2}{*}{$\begin{array}{c}\text { No. of the } \\
\text { wall }\end{array}$} & \multicolumn{2}{|c|}{ Breaking force, } & \multicolumn{1}{c|}{ Wall fracture pattern } \\
\cline { 2 - 3 } & $\mathbf{k g}$ & $\mathbf{\%}$ & \multicolumn{1}{c|}{ Broke in halves (fig. 13, a) } \\
\hline 1 & 1.890 & 100 & $\begin{array}{l}\text { The plates are intact. The plates with brick } \\
\text { fragments tore off the wall and the wall broke } \\
\text { (fig. 13, b) }\end{array}$ \\
\hline 2 & 8.650 & 457.6 & $\begin{array}{l}\text { The fiber is intact. From one side or the wall, at its } \\
\text { lower part, the ends of the fiber tore out fragments } \\
\text { of bricks and the wall cracked (fig. 13, c) }\end{array}$ \\
\hline 3 & 7.250 & 383.6 & $\begin{array}{l}\text { The fiber is intact. From one side or the wall, at its } \\
\text { lower part, the ends of the fiber tore out fragments } \\
\text { of bricks and the wall cracked (fig. 13, d) }\end{array}$ \\
\hline
\end{tabular}




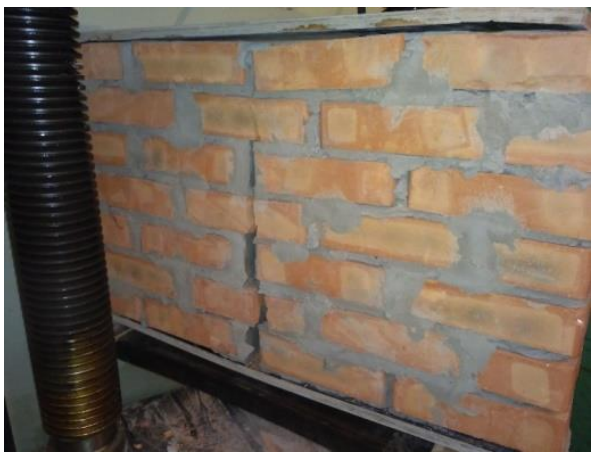

a

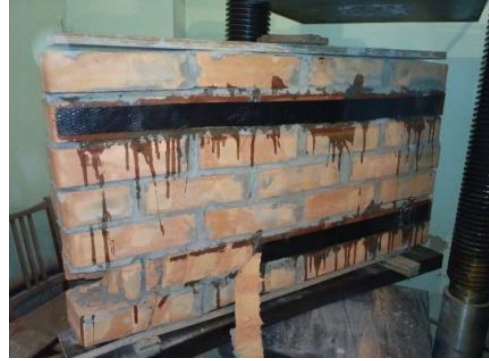

C

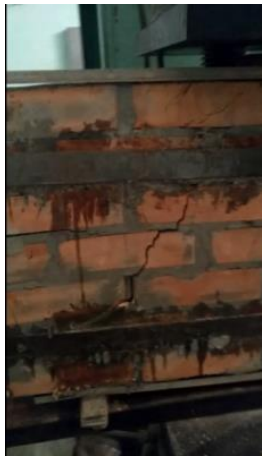

b

Fig. 13. Brick walls fracture pattern after they underwent strength tests

The analysis of experimental test results enables us to claim that strengthened brick walls can withstand significantly larger loads as compared to non-strengthened ones. It should be mentioned that brick wall strength depends on the strengthening type and base preparation. Bending strength of a wall strengthened by carbon fiber with pre-coating of the strengthening areas with primer is $11,500 \mathrm{~kg}$ and bending strength of a wall strengthened by the same methods without primer coating is $7,250 \mathrm{~kg}$, i.e., 1.5 times lower. 


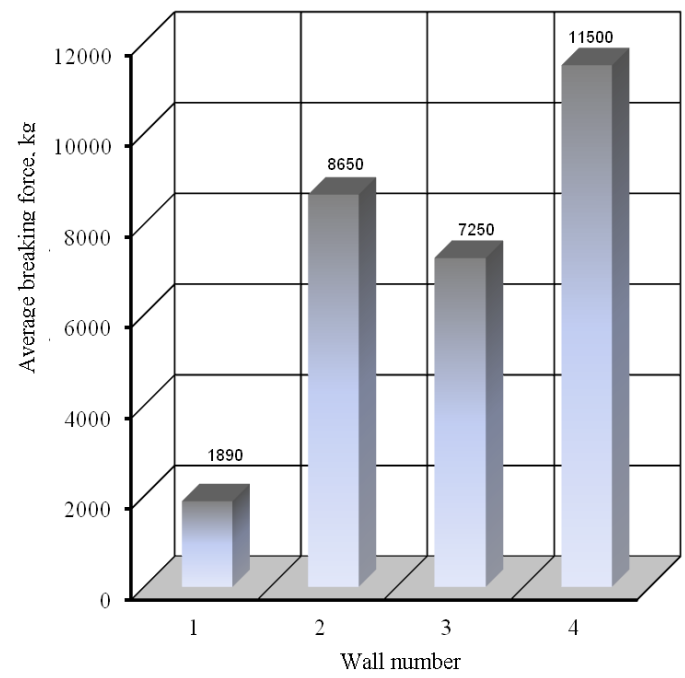

Fig. 14. Histogram of the breaking force in different methods of brick wall strengthening

\section{CONCLUSIONS}

The experimental tests conducted to identify the impact of the technological factor, i.e. the preparation of the brick base before gluing steel plates thereon, established that coating brick surface with Consolid-1 liquid primer increases the strength of adhesion of the plates to the bricks. Here, the strength of adhesion of the plates to the bricks raises with the increase of the amount of primer applied. Application of $9 \mathrm{~kg} / \mathrm{m}^{2}$ of primer allows to increase the adhesion of the plates to the bricks by $257.7 \%$.

The stage II experimental test results lead to the conclusion that strengthened bricks can withstand significantly larger loads as compared to non-strengthened ones. It should be mentioned that brick strength depends on the strengthening type. For example, bending strength of a brick strengthened by carbon fiber with pre-coating of the surface with primer is $728.5 \%$ higher than the one of a non-strengthened brick. In addition, if bricks are strengthened with steel plates glued to the surface pre-coated with primer, its strength will increase up to $978.5 \%$ as compared with the strength of non-strengthened bricks.

The analysis of stage III experimental test results enables us to claim that strengthened brick walls can withstand significantly larger loads as compared to non-strengthened ones. It should be mentioned that brick wall strength depends on the strengthening type and base preparation. Bending 
strength of a wall strengthened by carbon fiber with pre-coating of the strengthening areas with primer is $11,500 \mathrm{~kg}$ and bending strength of a wall strengthened by the same methods without primer coating is $7,250 \mathrm{~kg}$, i.e., 1.5 times lower. In total, such wall's bending strength is $608.4 \%$ higher as compared to a non-strengthened wall.

\section{SUMMARY}

From the analysis of technical inspection reports developed by the State Enterprise "V.S. Balitsky Research Institute of Building Production" it has been established that $85 \%$ of brick buildings over 30 years of age have cracks on their walls. The causes for brickwork fracture are: the increased load on these constructions due to the replacement or strengthening of upper constructions or replacement of technological equipment by items whose mass exceeds the mass of the ones used before the reconstruction, loss of bearing strength caused by operation: dynamic load, corrosive operational environment or atmosphere, improper operation, random damages, accidents. Current regulations and technical literature offer the following ways of strengthening or restoring the bearing strength of brick walls: full or partial replacement of the existing brickwork; injection of cracks; introduction of various strengthening elements; external reinforcement.

The technology of strengthening brick walls with external reinforcement using composite fibers, plates (lamellae) or grids glued onto the wall surface is widely used globally. However, virtually no domestic research is done in this area.

For this reason, the author conducted a number of experimental tests to develop and improve the technology of strengthening brick constructions with composite fibers glued to the wall surfaces.

The experimental tests conducted to identify the impact of the technological factor, i.e. the preparation of the brick base before gluing steel plates thereon, established that coating brick surface with Consolid-1 liquid primer increases the strength of adhesion of the plates to the bricks. Here, the strength of adhesion of the plates to the bricks raises with the increase of the amount of primer applied. Application of $9 \mathrm{~kg} / \mathrm{m}^{2}$ of primer allows to increase the adhesion of the plates to the bricks by $257.7 \%$.

The stage II experimental test results lead to the conclusion that strengthened bricks can withstand significantly larger loads as compared to non-strengthened ones. It should be mentioned that brick strength depends on the strengthening type. For example, bending strength of a brick strengthened by carbon fiber with pre-coating of the surface with primer is $728.5 \%$ higher than the one of a non-strengthened brick. In addition, if bricks are strengthened with steel plates glued to the surface pre-coated with primer, its strength will increase up to $978.5 \%$ as compared with the strength of non-strengthened bricks. 
The analysis of stage III experimental test results enables us to claim that strengthened brick walls can withstand significantly larger loads as compared to non-strengthened ones. It should be mentioned that brick wall strength depends on the strengthening type and base preparation. Bending strength of a wall strengthened by carbon fiber with pre-coating of the strengthening areas with primer is $11,500 \mathrm{~kg}$ and bending strength of a wall strengthened by the same methods without primer coating is $7,250 \mathrm{~kg}$, i.e., 1.5 times lower. In total, such wall's bending strength is $608.4 \%$ higher as compared to a non-strengthened wall.

\section{REFERENCES}

1. ДСТУ-Н Б В.1.2-18:2016 Настанова щодо обстеження будівель і споруд для визначення та оцінки їх технічного стану. - Київ: ДП «УкрНДНЦ», 2017. - 47 с.

2. ДСТУ Б В.3.1-2:2016 Ремонт і підсилення несучих i огороджувальних будівельних конструкцій та основ будівель i споруд. - Київ: ДП «УкрНДНЦ», 2017. - 72 с.

3. Савйовський В. В. Реконструкція будівель i споруд / В. В. Савйовський. - К.: Видавництво Ліра-К, 2018. - 320 с.

4. СТО 221 НОСТРОЙ 2.9.142-2015 Восстановление и повышение несущей способности кирпичных стен Проектирование и строительство. Правила, контроль выполнения и требования к результатам работ. - М.: «Издательство «БСТ», 2013. - 114 с.

5. Angelo Garofano. Structural behaviour of masonry walls strengthened with mortar layers reinforced with FRP grids. Master's Thesis. - Czech Republic, 2011. - 124 p.

6. Saman Babaeidarabad. Masonry walls strengthened with fabricreinforced cementitious matrix composite subjected to in-plane and out-ofplane load. Dissertation. - Coral Gables, Florida, 2013. - 147 p.

7. Костенко А. Н. Прочность и деформативность центрально и внецентренно-сжатых кирпичных и железобетонных колонн, усиленных угле- и стекловолокном. Автореферат диссертации на соискание ученой степени кандидата технических наук, Спец. 05.23.01. M., 2010. 29 c.

\section{Information about the author: Molodid O. S.,}

$\mathrm{Ph} . \mathrm{D}$. in Engineering, Associate Professor, Assistant Professor at the Construction Production Technology Department, Kyiv National University of Construction and Architecture 31, Povitroflotskyi Ave., Kyiv, 03037, Ukraine 